\title{
Trajectories of Education Policy-Making in Ghana: Exploring the Journey to Depoliticisation Process
}

\author{
Ibrahim Mohammed Gunu, PhD \\ Lecturer and Postgraduate Programmes Coordinator \\ Faculty of Education, \\ University for Development Studies
}

\begin{abstract}
This paper examines education policy-making in Ghana. It focuses on the roles different policy actors should play to depoliticise the process of education policy-making. The depoliticisation agenda as contains in this presentation has the potential to promote Sustainable National Development. This paper examines how far key actors like political parties and academics matter in the depoliticisation of education policy issues in Ghana. Drawing on Foucault discourse theory, past and present education policymaking processes are examined through a review of documents and literature. The analyses show that the current education policy-making procedure in Ghana is largely dependent on the ruling party manifesto and through committees or commissions setup by the ruling governments to determine educational policy issues. The educational policies as contained in the ruling party manifesto and committees or commissions reports are reproduced in national legislation by the government. These legislative arrangements often receive the endorsement of the majority in parliament and in the fourth republic for now, the ruling party is always in majority. The partisan politics associated with these processes are largely responsible for the politicisation process. Overall, this paper argues that evidence-based policy and practice can potentially reduce partisan politics in education policy-making in Ghana.
\end{abstract}

Key words: Education policy; Politicisation; Depoliticisation; Policy actors; Manifesto

\section{INTRODUCTION}

In this presentation education policy-making processes in Ghana are discussed. The focus is on the roles different actors participating in education policy-making in Ghana can play to depoliticise the process. Drawing on Foucault $(1974,2002)$ discourse theory, past and present education policy-making processes are examined through analysis of documents and literature. The main aim of this paper is to contribute to the understanding of the ways key actors have influenced education policy-making and to explore the means of depoliticising education policy-making in Ghana. This paper therefore examines issues of depoliticisation in education policy-making regime in Ghana. This task requires first and foremost the explanation of the various terminologies to establish the critical issues surrounding education policymaking. These terms are education policy, politicisation, and depoliticisation.

Education Policy in this context refers to policy text, policy discourses and policy effects (see Ball, 1993, 1994; 2013; Halpin and Troyna, 1995). Policy text refers to "the documents and speeches that 'articulate' policies and policy ideas" (Ball, 2013:7). Policy discourses refer to the context within which;

"individuals and groups of 'policy intellectuals' play an important role in establishing credibility and "truthfulness", and some of these people will be introduced later as a way of putting "faces" to policies. At moments of crisis or change such intellectuals play a key role in discursive struggles" (Ball 2013:7). 
Ball (2013) highlights that education policy-making is expected to be led by "policy intellectuals" (p.7) like the academics and be informed by evidence-based policy and practice developed through the stages of conception, development, implementation and evaluation (see Nudzor, 2014; Ibrahim 2017). Policy effects on the other hand refer to the impact of educational policy on practice and social justice; this includes performativity and general conditions of service (see Ball, 1993; 2008). For example, several years of policy reforms in UK and possibly in US and Canada had impacted greatly on teachers work regarding curriculum, school organisation and general conditions of work in the schools (see Ball, 1993). In Ghana for instance, the increase in duration of senior high school from 3 to 4 years in 2007 by the NPP government and the subsequent reversal to 3 years by the NDC government in 2009 and the recent government policy on free senior high school have had very different implications for schools, headteachers, students, parents and classroom teachers.

Guided by evidence-based issues this kind of policy-making should engage appropriate stakeholders in the process. Ball (1994:16) argues that these policies are;

"the product of compromises at various stages (at points of initial influence, in the micropolitics of legislative formation, in the parliamentary process and in the politics and micropolitics of interest group articulation). They are typically the cannibalized products of multiple (but circumscribed) influences and agendas. There is ad hocery, negotiation and serendipity within the state, within the policy formulation process".

Another terminology that needs clarification is Politicisation. Politicisation is defined by Longman Dictionary of Contemporary English (2009) as a process of making "a subject or a situation more political". This relates to issues that enable a political party to gain advantage in respect of votes and popularity. Depoliticisation in this respect is defined as "the process of moving decision-making and implementation responsibilities away from politicians with the aim of avoiding unwarranted political interferences that stall development" (Boateng 2017:371; see also Buller and Flinders 2005: 526-8).

Boateng (2017) interprets depoliticisation in the context of "depoliticised institutional arrangement" (p.369) capable of weaning programmes or project from political interference. This allows uninterrupted implementation of programmes or projects by the technocrats. He argues that this "is more effective when it is coerced by a donor with the capacity to impose costly sanctions when breaches occur" (p.369). In the context of education policy-making in Ghana and in the absence of international donors the citizenry whose resources (in the form of taxes) are involved, policy think tanks, and civil society, including labour unions should hold the government accountable. Drawing on Boateng (2017) three strategies are involved; the handling of educational policy decisions by apolitical institutions, increased transparency and decreased political discretion which allows politicians to work in lines with the rules.

In this respect depoliticisation supported by evidence-based policy and practice is the main argument of this paper. This paper contributes to the debate of depoliticisation of educationpolicy but takes a different approach to the issue by focusing on the evidence-based policy and practice which the academics have a greater responsibility to drive.

An understanding of the above explained terminologies are critical in examining the epistemological and ontological constructions which govern policy making in Ghana. In the following the paper examines the methodological approach in this paper. 


\section{METHODS}

The paper adopts documentary analysis (see Bryman, 2011; 2015) as a design for the study. Foucault's (1972) discourse theory (see Ball, 1990) is the theoretical lens which aided the broader analyses of Ghanaian educational commissions or committees' reports, political party manifestos, relevant literature and some acts of parliament. This analysis provided critical perspectives on educational policy text generation, policy discourses and related effects. The analysis covered the period from 1920 to 2018.

Discourse in Foucauldian context governs and "influences how ideas are put into practice and used to regulate the conduct of others" (Hall, 2001:72). The analysis in this context involved policy documents, review of existing literature and the media (see also Peters \& Burbules, 2004; Peters, 1996). The analysis focuses beyond the central government to include the interest groups (like political parties, policy think tanks, academics and the likes) and the discourses that shape education policy debate in Ghana.

The research was conducted from August 2017 to February 2018 and presented at the University for Development Studies, 2018 Harmattan International Conference on February 8, 2018. The Theme of the conference was Depoliticizing Education for National Development: The Role of Academia, Civil Society Organisations and Development Partners. The constructive feedback provided at the conference helped to shape this article.

\section{ANALYSIS AND FINDINGS}

\section{Historicising the Politics of Educational policy-making discourse in Ghana}

The analysis in this section is presented in a specific Ghanaian historical context. This kind of discourse demonstrates how education policy and practices are produced. Indeed, till the independence of Ghana in 1957, the education of Gold Coasters (present Ghanaians) was undertaken by a succession of regimes or different nations - Portuguese from 1529, the Dutch in 1644, the Danes in 1727 and the English in 1663-1665 and re-established in 1766 (George 1976; Kimble 1963 see also Bourret, 1960) to the time of Ghana's independence. From the 1920 s to the early 2000s education policy issues in Ghana have largely been committee-based (Nudzor, 2014) and gradually moving towards manifesto-based cum committees from 2008 to present (see Ibrahim, 2017).

The educational policies as contained in the ruling party's manifesto and committees or commissions reports are reproduced in national legislation by the government. For example, the passage of Education Amendment Bill 2010 to amend education Act 778 to reverse the four-year Senior High School to three years as was contained in the 2008 NDC Manifesto. These legislative arrangements often receive the endorsement of the majority in parliament and in the fourth republic in Ghana the ruling party has been the majority in the national legislative Assembly from 1992 to present (2018). The partisan politics associated with these processes are largely responsible for the politicisation process. These political discursive practices lead to tension and reduces confidence in the educational system. Overall, this paper argues that evidence-based policy and practice can potentially reduce partisan politics in education policymaking in Ghana.

In the fourth republic starting from 1992 to 2016, the recurring themes in the policy documents (manifestos and committees or commissions reports) of the two major political parties in Ghana, NPP and NDC, (these two political parties have been in and out of government) largely concentrated on promises like the provision of facilities, quality education, access, vocational oriented education, costs cutting, effective education system in 
Ghana, free basic education, progressive free secondary education and free secondary education (Akyeampong et al. 2007; Little 2010; Little \& Lewin, 2011).

From 2008 to present, the "manifestolisation" (Ibrahim 2017) of education policy which seeks to castigate the educational policies of political opponents gradually found its way into the education policy discourses in Ghana. This allowed the two major political parties to make provision in their manifestos to castigate the opponents' education policy thereby fuelling the notion of politicisation and political polarisation in the education policy-making process.

The incorporation of educational policy directions in political party manifestos make political parties key actors in an ongoing debate regarding depoliticisation of education in Ghana. This paper argues that the depoliticisation process should start with education policy prescriptions. Very mindful of the fact that ruling government is constituted by a political in Ghana, this paper sees the engagement of political parties as very vital to the process. In the following the paper examines the committees and commissions established by successive governments to investigate education policy issues in Ghana.

\section{Committees or Commissions}

This part examines the various committees or commissions established in Ghana to review and determine education policy directions in Ghana. These committees are considered in the following:

- Educationists Committee in 1920; the focus of this committee recommendation was an expansion in basic education in Ghana. The castle schools and mission schools provided the opportunity for basic education in Ghana at the time of this recommendation. Moral education was also included in this recommendation for character training in our schools (Fredua-Kwarteng, 2015).

- Mills-Odoi Commission in 1966; this committee recommended the centralisation of school management in secondary education. The inspection of private schools was to be carried regularly as it was pertaining in the public schools (Fredua-Kwarteng, 2015).

- Kwapong Review Committee in 1970; The structure of education which was recommended by this committee include; 6-year primary education, 3-year junior secondary education, and three-years of senior secondary education was adopted by Dzobo Commission. Indeed, the Busia regime partly experimented this policy between 1969 to 1972 (Fredua-Kwarteng, 2015).

- The Dzobo Commission in 1974; This commission recommended 6-year primary education, 3-year junior secondary education, and three-years of senior secondary education. These recommendations were implemented on experimental basis by Busia's administration in 1969-1972 (Fredua-Kwarteng, 2015:85).

- The Education Commission on Basic and secondary Education in 1987; this commission explored the means of implementing the JSS and SSS education system as contained in the Dzobo commission's recommendations (Fredua-Kwarteng, 2015:85).

- The Education Reform Review Committee in 2002; This committee recommended the need for capitation grants to increase access to education, two-year kindergarten education, six-year primary education, three-year JSS education (Fredua-Kwarteng 2015; Nudzor, 2014; Little 2010:27). Following the work of the review committee the government of president Kufour accepted the recommended structure of education, introduced the capitation grant scheme in 2005, increased the duration of the SSS from 3 to 4 years and changed the names from Junior Secondary School (JSS) and Senior Secondary School (SSS) to Junior High School (JHS) and Senior High School (SHS) in their respective order in 2007 (Fredua-Kwarteng 2015; Nudzor, 2014; Little 2010). 
However, in 2009 following the victory of NDC in the 2008 general election the duration was revised from 4 years to 3 years.

The key issues associated with the workings of these committees are, the government of the day always appoints the chair persons of the committees or commissions, determines members, provides their terms of reference, receives their recommendations and issues white papers to adopt, alter or reject some of the recommendations of the committees or commissions (Fredua-Kwarteng, 2015).

Also, these committees and commissions play an advisory role, and their functions are limited to the terms of reference provided by the government. The workings of the committees and commissions are not legally binding on the governments that appoints them but depending on the calibre of the people who constitute the membership of the committees they could influence the decisions of the government (Fredua-Kwarteng 2015: Ibrahim, 2017).

In addition, the committees and commissions are transient in nature and are expected to be dissolved after the submission of their report to the government (Fredua-Kwarteng 2015; Nudzor, 2014). This is indication that it might not have the opportunity to clear itself from the possible misunderstanding and misapplication of its report. For example, Anamuah Mensah Committee report 2002 was interpreted and implemented differently by the NPP (the government that sets up the committee) and NDC regarding the duration of SHS. In the following the paper examines political party manifestos and partisan politics in education policy-making.

\section{Manifestolisation of Education Policy and Partisan Polarization or Politics}

Political party Manifesto highlights the vision of the party and its competitive strategy (see Eder, Jenny \& Müller, 2017). This is the document in which political parties make their promises to be implemented when political power is captured or retained. Allen \& Mirwaldt (2010: 872) argue that "manifestos contain the ideas, values and policies that parties consider to be most important, or which they think will resonate with voters".

Political parties in Ghana rally behind the political party manifesto to contest the general election. This document outlines the party's positions, key priority areas and generally their promises. In Ghana Manifestos are approved by party representatives at the party's national delegates congress. These manifestos "are written by party elites with additional electoralstrategic considerations in mind" (Elischer, 2012:644).

The political parties before Independence in Ghana focused on manifestos to deliver their messages on critical issues like economic development, health and the likes. For the sake of illustration this paper concentrates on the major two political parties at the time of independence and in the fourth republic as it is not within the scope of this article. In the first elections in 1951 UGCC and CPP produced the first manifestos (Ayee 2011) which were entitled "Plan for the Nation" and, "Towards the Goal" respectively (Ayee 2011). In the fourth republic where manifesto messages have greater influence on the electoral fortunes of political parties (Ayee, 2011; Alabi, 2007) clarity of party manifesto messages and titles are critical. It is established that the message of "Positive Change" by NPP as compared to the NDC's campaign message of "Spreading the Benefits of Development" won the election for NPP in 2000 elections (Ayee 2011; 46). Also, the NDC's "I care for you" manifesto pledge played the magic for NDC in 2008 election (Ayee, 2011; 47). The manifesto gives political parties the opportunity to communicate their message to the electorate. 
The usage of party manifesto to communicate specifically party educational programmes became mucky when the 2008 NDC manifestos intentionally castigated the educational policies and programmes of the ruling NPP government and pledged to reverse it while in opposition. When NDC won political power in 2008 the decision by the Kufour administration in 2007 to change the duration of the SHS from three years to four years was reversed to three years. These issues marked political polarisation of education policy-making in Ghana as arguments regarding this duration was reduced to political affiliations in Ghana. The manifesto engineered policy reversal of the duration of the SHS fuelled polarization in the education policy-making in Ghana.

The 3year SSS programme began in 1990 lasting up till the time of the change in duration in 2007; about 17 years of its implementation. However, it is not very clear what evidence-based policy and practice informed the decision of the government to increase the duration from 3 to 4 years. But when the NDC assumed office in 2009 in less than two years of its implementation the duration was reserved with the explanation that there were no adequate facilities in the school to accommodate the fourth-year students (Little 2010; Fredua-Kwarteng 2015; Nudzor, 2014; NDC 2008).

Even though it might be reasonable to assume that 17 years of the implementation of the 3year duration provided enough time and thinking as to the reasons for an increased in the duration by one year as compared to two years of the new policy implementation (2007-2009) as the first badge of the new structure was yet to be produced, we must not fall prey for unexamined empirical evidence.

The 2012 elections manifesto drives, saw the NPP campaigning for free SHS whilst the NDC campaigned for quality education. The aftermath of the 2012 general election, specifically September 2016, saw the NDC government which campaigned against the free SHS policy of NPP implementing progressive free SHS policy initiative, raising unprecedented levels of debates in the media and among the public about the real intentions of the ruling NDC government (see NDC, 2012; NPP, 2012).

In addition, the 2016 manifesto drives of NPP on free SHS intensified as the ruling NDC government implemented the progressive free SHS policy initiative which potentially was a motivation. The free SHS campaign possibly was part of the wining magic of the NPP in the 2016 elections. The quick implementation of the free SHS in 2017/2018 academic year (which was contained in NPP 2016 manifesto) as NDC did in the reversal of the duration of SHS from 3 to 4 years in 2009 reduced the debate of the implementation to partisan politics. The several educational manifesto pledges of NPP included funding, which includes scholarships for students at SHS and restoration of teacher trainees and nursing trainees' allowances.

The above explanation supports the arguments of Grace (1995:3) that "many contemporary problems or crises in education are, in themselves, the surface manifestations of deeper historical, structural and ideological contradictions in education policy". In the following the paper provides the reasons for the prescription of education policy in the manifesto.

\section{Reasons for Policy Prescription in Political Party Manifestos}

The following are the possible reasons for this trend:

- The growing need to capture many social interventions in various sectors including education in political parties' manifestos is partially responsible for the politicisation process. 
- Majoritarian interests; Provision of public education relates to serious consideration of the key issues. The poor and young voters are in majority; this possibly represent the majoritarian interests. It will therefore be politically prudent for any political party to pay attention to their needs for electoral advantage.

- In the current democratic dispensation in Ghana, some citizens hold the view that if politicians stay away from educational policy-making it will be proper. The same citizenry think that government should take the desirable steps to ensure that schools function properly and are often quick to blame the government for failure in the educational system. This phenomenon allows the government to intervene on issues relating to education in Ghana.

The historicism of education policy in Ghana as presented above points to the various discourses that characterise policy making in Ghana. Ball (1994: 4) states that this kind of historicism "identifies and counterpoints antagonistic discourses - the dominant and the silenced, the 'truthful' and illegitimate". These happenings inform education policies in Ghana and produce tensions and emotional debates about education policies in Ghana. In the following the paper examines reasons for the perceived politicisation of education policymaking.

\section{Reasons for the Perceived Politicisation Inadequate Accessible Studies/Literature}

Few accessible research studies on education policy-making and politics in Ghana like Nudzor (2014) exist. The reality is that how much studies have we done regarding the politicisation of education in Ghana rather than what political opponents or ruling governments and the main stream media have stated about the ruling government policies on education. Therefore, the perception of the politicisation of education in Ghana could be the imagination of the few articulate group in the Ghanaian society. Evidence-based studies are needed as a justification for the call for the depoliticisation process in Ghana. This paper sees the greatest research gaps in Education policy-making and politics research; there is dearth of education policy-making and politics research in Ghana.

\section{Inadequate Guidelines or Models of Depoliticisation}

The challenge for researchers who are involved in education policy and politics research is that few guidelines or models exist to follow as part of depolitciisation process (Lugg \& Murphy, 2014). An educational policy introduced by one government which gets changed by another government could be seen in the light of politicisation.

\section{Political Party Manifesto and its Role in the Perceived Politicisation of Education}

Political parties come to power with an approved manifesto. This becomes basis upon which the mandate is granted. Therefore, if it is does not implement the promises it would be deemed to have deviated from the approved mandate of the people. However, this paper presents an argument that the emotional reversal of education policies of political opponents without evidence-based justification might not help in the development of Ghanaian education system.

This presupposes that It is not sufficient to state that the policy review was in the party's manifesto pledge therefore non-implementation will mean deviating from the approved mandate of the electorate (see Ibrahim, 2017). The author as a voter himself in the fourth republic in Ghana, suspects that many Ghanaians are unaware of the manifesto promises of political parties and the few who are aware do not take them seriously as many of them are not implemented before the tenure of the government ends and at the same time the manifesto pledges are not legally binding on the political parties (see Ibrahim 2017). Political party 
manifesto positions on election and post-election politics on education are issues promoting the perceived politicisation notion.

The worrying trend is that all political parties make promises without knowing the cost involved. Ayee (2011:373) states that "there is little time spent on how the policies and programmes in the manifestos would be financed, for instance, making them each a wish list instead of a properly researched set of policy alternatives". This paper hopes to find the lead way for these problems.

\section{The Politics of the Depoliticisation of Education Debate}

The precision regarding how we recognise the ingredients of politicisation and depoliticisation empirically in Ghana is critical. How we shape our understanding of the depoliticisation mantra is essential. Depoliticisation could be treated as a threat to political opportunities. Politicisation and depoliticisation dynamics require appreciation of the attitude of politicians and individuals who speak, and support issues based on their political affiliations.

For instance, reducing the debate of education policy-making to partisan affiliations could affect the process and cast doubts on the real intentions of the people involved including politicians. The analytical implication of this paper is to present the justification for evidencebased policy and practice. In the following the paper examines the role of transnational institutions in education policy-making in borrowing member states.

\section{The Role of Transnational Institutions in Educational Policy Making}

The World Bank which is one of international organisations is the biggest external loan provider for education programmes in the world. It is assisting countries to shape their education policy-reviews and changes. Because of dwindling financial resources in the 1980s Ghana received financial support from the World Bank under the economic recovery programmes (Moutsios, 2010). This financial support allows the World Bank to advance the organisation's policies in most of the borrowing states worldwide (Moutsios, 2010).

The World Bank, the International Monetary Fund (IMF) and the World Trade Organisation (WTO) are perusing educational programmes in partner countries to ensure human capital development and achieve financial stability. The World Bank achieves this by providing credit facilities to assist the education sector reforms in borrowing countries and promote worldwide education policies in line with the service of the global economy (see Moutsios, 2010; Newitter, 2016a, 2016b \& 2015; Ball, 2013).

The development of knowledge economy which has an implication for education policymaking and changes is what is pushing the World Bank to assist nations to translate this into policy prescriptions (Ball, 2013). This kind of World Bank support is geared towards "helping developing countries to equip themselves with the highly skilled and flexible human capital needed to compete effectively in today's dynamic global markets" (Ball, 2013:24). It is therefore significant for one state that these transnational organisations promote some educational policies in borrowing member states in line with global economic development. In the following the paper examines strategies for depoliticising education policy-making in Ghana.

\section{STRATEGIES FOR DEPOLITICISING EDUCATION POLICY-MAKING IN GHANA}

It is significant for one to make a distinction between political interference and political intervention (see Boateng, 2017: 370). The later could be employed to solve a problem that is 
bedevilling the educational sector. Education policy-making is inherently political (Nutley, Davies \& Walter, 2002) but not partisan politics.

The debate about depoliticising or avoidance of partisan politics in education policy-making in Ghana is a long standing one. In Ghana the last decade has seen extensive debates about the nature of educational policy making and concerns have been expressed about the extent to which governments have rushed to implement educational promises contained in their manifesto. The following are some of the strategies to the depoliticisation process:

\section{Evidence-based Policy and Practice}

The purpose in this section is to reflect critically on how political parties and government can be supported to give meaning to evidence-based policy and practice in Ghana. Evidence-based policy will ensure that policy reviews or reforms and changes are better informed by the available evidence (Nutley et. al. 2002 and see also Hargreaves, 1997; Hurts, 2003). In 1999 the Cabinet Office of UK defines the evidence-based policy and practice (EBPP) strategy as: "Expert knowledge; published research; existing statistics; stakeholder consultations; previous policy evaluations; the Internet; outcomes from consultations; costings of policy options; output from economic and statistical Modelling" (Strategic Policy Making Team, 1999 cited in Nutley, Davies et. al. 2002:2).

Davies, Nutley \& Smith (2000) argue that evidence-based approach in education could be challenged because of stakeholders, like parents, and politicians, "strongly held views about what constitutes an effective intervention. Such views may conflict with rigorously obtained research evidence but nonetheless they will influence both policy and practice" (p.358). In this instance evidence-based policy and practice is the prime driver, this may require compromises at the implementation stage. This process of policy engineering is considered as one which provides "the most technically correct answers" (Fay, 1975:14 cited in Ball, 1995:259) to solving issues. The policy in this context is "de-politicised and thoroughly technicised" (Ball, 1995:259; see also Hargreaves, 1997).

\section{Teacher Driven Research}

Teachers should be encouraged and supported to conduct research in the schools. These teachers who are working in the schools can help provide information for school improvement. This resonates with the concept of "educational action research" (Carter \& Halsall, 1998:72). Drawing on Ball (1997) interpretation of Foucault (1977:194), this presentation relies on Foucault argument that "power produces; it produces reality ... the individual and the knowledge that may be gained of him belong to this production". The coordinating role of this kind of research should be in the hands of the academics.

\section{The Role of Societal Actors}

The role of societal actors in the promotion of evidence-based policy and practice in education in Ghana is crucial. The actors in Ghana include the Institute of Economic Affairs (IEA), Ghana National Association of Teachers (GNAT), Institute of Democratic Governance (IDEG), IMANI Ghana, National Association of Graduate Teachers (NAGRAT), Ghana Center for Democratic Development (CDD-Ghana) and the likes. For example, the Institute of Economic Affairs (IEA) provides an opportunity for presidential candidates to present their programmes to the electorate. This platform assists them to market their manifestos. The IEA in this direction assisted in the organisation of presidential debates in 2000, 2004, 2008, 2012 and 2016. The institute also supported political parties in 2008 to print their manifestos. This support was duly acknowledged by all the political parties (see Ayee 2011). Also, IDEG and its Danish partners, Radikale Venstre, in 2016 organised "Manifesto Clinic" to support political parties to 
develop alternative policies in their manifestos. All these examples are provided to substantiate the claim that societal actors can be supportive in this direction.

Strengthening the role of National Development Planning Commission (NDPC) (see 8 (86) of the 1992 Constitution):

While recognising that it is significant to maintain article 86 of the 1992 Republican Constitution (the constitutional provision on the National Development Planning Commission) as entrenched constitutional provision there is the need for important amendments to be made to it if the NDPC is to effectively execute its constitutional mandate. The amendment called for is to ensure that the NDPC is ran primarily by academics. To achieve this, it is recommended that clause $2(\mathrm{v})$ and (vi) of article 86 of the Constitution should be amended to include a requirement that a candidate for appointment under those provisions should be an academic of a rank not below the equivalence of a senior lecturer of an institution of high learning in Ghana. Also, other significant stakeholders in the country like the Governor of the Bank of Ghana, the Government Statistician should be included. In addition, the chair person should be appointed by the commission members themselves. Moreover, the workings and decisions of this commission should be legally binding on the government. Finally, ministers of state should be taken out of the membership. These amendments and composition would position NDPC to coordinate evidence-based policy and practice issues in the education policy-making in Ghana.

\section{CONCLUSION}

The Foucauldian discourse analysis enabled the researcher to construct the process of policy making in Ghana that potentially can reduce partisan politics. The analyses in this paper showed that recent national education policy-making in Ghana is more committee or commission cum manifesto based. The committees or commissions arrangements allow the government of the day to set up committees or commissions with terms of reference, in some instances, to conduct nationwide consultations. The educational policies as contained in the ruling party manifesto and committees or commissions reports are reproduced in national legislation by the government. These legislative arrangements often receive the endorsement of the majority in parliament and in the fourth republic for now, the ruling party. The partisan politics associated with these processes are largely responsible for the politicisation process. The paper therefore argues that evidenced-based policy and practice engineered by academics can potentially reduce partisan politics in education policy-making in Ghana. The presentation also argues that Africa Union (AU) should establish its own initiatives to assess educational programmes and progress in member states. This should assist African countries to develop their education beyond aid prescribed policies.

\section{References}

Akyeampong, K., Djangmah, J., Oduro, A., Seidu, A., and Hunt, F. (2007). Access to basic education in Ghana: The evidence and the issues -Country Analytic Report.

Alabi, J., and Alabi, G. (2007). Analysis of the effects of ethnicity on political marketing in Ghana. International Business and Economics Research Journal, 6(4), pp.39-45.

Allen, N., and Mirwaldt, K. (2010). Democracy-speak: Party manifestos and democratic values in Britain, France and Germany. West European Politics, 33(4), pp.870-893. 10.1080/01402381003794662.

Ayee, J. R. (2011). Manifestos and elections in Ghana's fourth republic. South African Journal of International Affairs, 18(3), pp.367-384. 10.1080/10220461.2011.622951

Ayee, J. R. (2008). The evolution of the new patriotic party in Ghana. South African Journal of International Affairs, 15(2), pp.185-214. 10.1080/10220460802614064.

Ball, S. J. (1990). 'Introducing Monsieur Foucault'. In S.J. Ball (ed.), Foucault and education: Disciplines and knowledge. London: London: Routledge, pp.1-10. 
Peters, M. (1996). Poststructuralism, politics, and education. critical studies in education and culture. London: Bergin \& Garvey, pp.79-110.

Ball, S. (1993). Education policy, power relations and teachers' work. British Journal of Educational Studies, 41(2), pp.106-121.

Ball, S. J. (1994). Education reform a critical and post-structural approach. Buckingham: Buckingham Open University Press, pp.1-64.

Ball, S. (1995). Intellectuals or technicians? the urgent role of theory in educational studies. British Journal of Educational Studies, 43(3), pp.255-271. 10.1080/00071005.1995.9974036.

Ball, S. J. (2008) 'Performativity, privatisation, professionals and the state'. In B. Cunningham (ed.). Exploring professionalism. London: Institute of Education, University of London, pp.50-68.

Ball, S.J. (2013) The education debate. 2 edn. Bristol: Policy, pp.6-117.

Ball, S. J. (2012). In Maguire M., Braun A. (Eds.), How schools do policy; policy enactments in secondary schools. London: London: Routledge, pp.1-6.

Boateng, O. A. (2017). Donor- induced depoliticisation of development implementation: The case of Ghana's compact I. Development in Practice, 27(3), pp.368-379. 10.1080/09614524.2017.1296934.

Brierley, S. (2012). Party unity and presidential dominance: Parliamentary development in the fourth republic of Ghana. Journal of Contemporary African Studies, 30(3), pp.419-439. 10.1080/02589001.2012.701844.

Bryman, A. (2011) Social Research Methods. Oxford: Oxford University Press, pp.37-219.

Bryman, A. (2015) Social Research Methods. 5th edn. Oxford: Oxford University Press, pp.37-71.

Buller, J., and Flinders, M. (2005). The domestic origins of depoliticisation in the area of British economic policy 1. The British Journal of Politics and International Relations, 7(4), pp.526-543. 10.1111/j.1467-856x.2005.00205.x

Hurst, K. (2003). What works? evidence- based policy and practice in public services. Journal of Health Organization and Management, 17(3), pp.225-226. 10.1108/jhom.2003.17.3.225.2.

Davies, H., Nutley, S. and Smith, P. (2000) 'Learning from the past, prospects for the future', in H. T. O. Davies, S. M. Nutley and P. C. Smith, what works? evidence- based policy and practice in public services. Bristol: The Policy Press, pp.351-362.

Eder, N., Jenny, M., and Müller, W. C. (2017). Manifesto functions: How party candidates view and use their party's central policy document. Electoral Studies; Electoral Studies, 45, pp.75-87. 10.1016/j.electstud.2016.11.011

Elischer, S. (2012). Measuring and comparing party ideology in nonindustrialized societies: Taking party manifesto research to Africa. Democratization, 19(4), pp.642-667. 10.1080/13510347.2011.605997.

Fredua-Kwarteng, E. (2015). Democratizing national education policy-making in Africa: A focus on Ghana. International Journal of Educational Studies, 2(2), pp.83-94.

Foucault, M. (1977) Discipline and punish: the birth of the prison. London: Penguin Books, pp.1-194.

Foucault, M. (2002). The archaeology of knowledge. London: London: Routledge, p.1-81.

Foucault, M. (1974). The archaeology of knowledge. London: London: Routledge, p.1-82.

Constitution of the Republic of 1992, Accra: Assemblies press.

Peters, M. A., and Burbules, N. C. (2004). Poststructuralism and educational research. Oxford: Rowman and Littlefield, p.55-82.

George, B.S. (1976). Education in Ghana. Washington, DC: US. Government Printing Office, pp.1-85.

Grace, G. R. (1995). School leadership beyond education management. an essay in policy scholarship. London: London Falmer, pp.1-6.

Hargreaves, D. H. (2007) 'In defence of research for evidence-based teaching: a rejoinder to Martyn Hammersley'. In M. Hammersley., and O. University. (eds). Educational research and evidence-based practice. London: SAGE, pp.43-64.

Hall, S. (2001) 'Foucault: Power, Knowledge and Discourse'. In M. Wetherell, S. Taylor, S. J. Yates and Open University (Eds.), Discourse theory and practice: A reader. London: London: SAGE, pp.72-81.

Halpin, D., and Troyna, B. (1995). The politics of education policy borrowing. Comparative Education, 31(3), pp.303-10. 
Ibrahim, M. G. (2017). Perspectives on student behaviour management in high schools in Ghana; exploring potential for positive behaviour management in policy and practice vols 1 and 2. PhD dissertation, Keele University.

Carter, K. and Hall, R. (1998) 'Teacher research for school improvement', R. Halsall (ed). Teacher research and school improvement opening doors from the inside. Buckingham: Buckingham Open University Press, pp.71-92.

Kimble, D. (1963). A political history of Ghana: The rise of gold coast nationalism, 1850- 1928. Oxford: Oxford Press, pp.1-10.

Little, A. W. (2010). Access to Basic Education in Ghana: politics, policies and progress. Project Report. CREATE, Brighton, UK, pp. 1-4.

Little, A. W., and Lewin, K. M. (2011). The policies, politics and progress of access to basic education. Journal of Education Policy, 26(4), pp.477-482. 10.1080/02680939.2011.555004.

Longman dictionary of contemporary English. 2009. Essex: Longman.

Lugg, C. A., and Murphy, J. P. (2014). Thinking whimsically: Queering the study of educational policy- making and politics. International Journal of Qualitative Studies in Education, 27(9), pp.1183-1204. 10.1080/09518398.2014.916009.

Moutsios, S. (2010). Power, politics and transnational policy- making in education. Globalisation, Societies and Education, 8(1), pp.121-141.10.1080/14767720903574124.

New Patriotic Party, Agenda for Positive Change: Manifesto of the New Patriotic Party. Accra: NPP, 2000, pp.1-6.

Newitter, M.D. (2015a). Ghana - Ghana Secondary Education Improvement Project: P145741 - Implementation Status Results Report: Sequence 03. Washington, D.C.: World Bank Group. [Online] Available at: <http://documents.worldbank.org/curated/en/682291468252309674/Ghana-Ghana-Secondary-EducationImprovement-Project-P145741-Implementation-Status-Results-Report-Sequence-03> [Accessed 20 September 2016].

Newitter, M. D. (2015b). Ghana - Ghana Partnership for Education: P129381 - Implementation Status Results Report: Sequence 06. Washington, D.C.: World Bank Group. [Online] Available at: http://documents.worldbank.org/curated/en/416111468030305855/Ghana-Ghana-Partnership-for-EducationP129381-Implementation-Status-Results-Report-Sequence-06 [Accessed 20 September 2016].

Newitter, M. D. (2016a). Ghana - Ghana Partnership for Education: P129381 - Implementation Status Results Report: Sequence 07. Washington, D.C.: World Bank Group. [Online] Available at: <http://documents.worldbank.org/curated/en/119131468031745122/Ghana-Ghana-Partnership-forEducation-P129381-Implementation-Status-Results-Report-Sequence-07> [Accessed 20 September 2016].

Newitter, M. D. (2016b.) Ghana - Ghana Secondary Education Improvement Project: P145741 - Implementation Status Results Report: Sequence 04. Washington, D.C.: World Bank Group. [Online] Available at: <http://documents.worldbank.org/curated/en/684271468037753016/Ghana-Ghana-Secondary-EducationImprovement-Project-P145741-Implementation-Status-Results-Report-Sequence-04> [Accessed 20 September 2016].

Nudzor, H. P. (2014). An analytical review of education policy- making and implementation processes within the context of "decentralized system of administration" in Ghana. SAGE Open, 4(2), pp.1-11. $10.1177 / 2158244014530885$.

Nutley, S., Davies, H. and Walter, I. (2002). Evidence based policy and practice: Cross sector lessons from the UK. ESRC UK Centre for evidence-based policy and practice: working paper, 9, pp.1-10.

\section{AUTHOR BIOGRAPHY}

Ibrahim Mohammed Gunu is a lecturer and postgraduate programmes coordinator at Faculty of Education, University for Development Studies, Tamale, Ghana. He holds Bachelor of Education (Primary Education) from University of Cape Coast, Ghana. He attained his Master of Arts (Adult Education) from University of Ghana and PhD in Education from Keele University, England. He is a Commonwealth Scholar. His areas of expertise and interest include Continuous Professional Development of workers, School Discipline, Educational Management and Policy Studies (including policy enactment) design, implementation and assessment of evidencebased educational programmes for both children and adults. 